\title{
THE IMPERATIVE NEED FOR NATIONALLY COORDINATED BIOASSESSMENT OF RIVERS AND STREAMS
}

Susan J Nichols ${ }^{\text {a }}$ (corresponding author), Leon A. Barmuta ${ }^{\mathrm{b}}$, Bruce C. Chessman ${ }^{\mathrm{c}}$, Peter E. Davies ${ }^{\mathrm{d}}$, Fiona J. Dyer ${ }^{\mathrm{a}}$, Evan T. Harrison ${ }^{\mathrm{c}}$, Charles P. Hawkins ${ }^{\mathrm{e}}$, Iwan Jones ${ }^{\mathrm{f}}$, Ben J. Kefford ${ }^{\mathrm{c}}$, Simon Linke ${ }^{\mathrm{g}}$, Richard Marchant ${ }^{\mathrm{h}}$, Leon Metzeling ${ }^{\mathrm{i}}$, Katie Moon ${ }^{\mathrm{c}}$, Ralph Ogden ${ }^{\mathrm{j}}$, Michael Peat ${ }^{\mathrm{a}}$, Trefor B. Reynoldson ${ }^{\mathrm{k}}$ and Ross M. Thompson ${ }^{\mathrm{c}}$

a Institute for Applied Ecology and MDBFutures Collaborative Research Network, University of Canberra, Australian Capital Territory AUSTRALIA Sue.nichols@canberra.edu.au, +61 (0)262015408 Fiona.Dyer@canberra.edu.au, Michael.Peat@canberra.edu.au

${ }^{\mathrm{b}}$ School of Biological Sciences, University of Tasmania, Hobart, Tasmania AUSTRALIA leon.Barmuta@utas.edu.au

${ }^{\mathrm{c}}$ Institute for Applied Ecology, University of Canberra, ACT AUSTRALIA bruce.chessman@canberra.edu.au, Evan.Harrison@canberra.edu.au, Ben.Kefford@canberra.edu.au, katieamoon@gmail.com, Ross.Thompson@canberra.edu.au

${ }^{\mathrm{d}}$ Centre for Environment and School of Biological Sciences, University of Tasmania, Hobart, Tasmania AUSTRALIA P.E.Davies@utas.edu.au

e Department of Watershed Sciences, Western Center for Monitoring and Assessment of Freshwater Ecosystems, and the Ecology Center, Utah State University, Logan, Utah USA chuck.hawkins@ @usu.edu

${ }^{\mathrm{f}}$ School of Biological and Chemical Sciences, Queen Mary University of London, London, UK j.i.jones@qmul.ac.uk

g Australian Rivers Institute, Griffith University, Queensland AUSTRALIA simon.linke@gmail.com

${ }^{\mathrm{h}}$ Museum Victoria, Melbourne Victoria AUSTRALIA rmarch@ museum.vic.gov.au

${ }^{i}$ Environment Protection Authority, Victoria AUSTRALIA Leon.Metzeling@epa.vic.gov.au

${ }^{\mathrm{j}}$ eWater, Bruce, ACT AUSTRALIA ralphogden4@gmail.com

${ }^{\mathrm{k}}$ Acadia University, Wolfville, Nova Scotia CANADA trefor.reynoldson@gmail.com 


\section{Abstract}

Declining water quality and ecological condition is a typical trend for rivers and streams worldwide as human demands for water resources increase. Managing these natural resources sustainably is a key responsibility of governments. Effective water management policies require information derived from long-term monitoring and evaluation. Biological monitoring and assessment are critical for management because bioassessment integrates the biological, physical and chemical features of a waterbody. Investment in nationally coordinated riverine bioassessment in Australia has almost ceased and the foci of management questions are on more localized assessments. However, rivers often span political and administrative boundaries, and their condition may be best protected and managed under national policies, supported by a coordinated national bioassessment framework. We argue that a nationally coordinated program for the bioassessment of riverine health is an essential element of sustainable management of a nation's water resources. We outline new techniques and research needed to streamline current arrangements to meet present-day and emerging challenges for coordinating and integrating local, regional and national bioassessment activities. This paper draws on international experience in riverine bioassessment to identify attributes of successful broad -scale bioassessment programs and strategies needed to modernize freshwater bioassessment in Australia and re-establish national broad-scale focus.

Additional keywords: Freshwater monitoring; biological assessment; broad-scale; water quality; streams; rivers

\section{Introduction}

The wellbeing of any nation is strongly connected to its freshwater ecosystems, and this is particularly so in Australia, being the driest inhabited continent. Yet the multiple and often competing demands on water for people, livestock, and industry have adversely affected many of Australia's aquatic environments (Norris et al. 2001a). Consequently, many populations of distinctive aquatic flora and fauna have declined, and some are close to extinction (Koehn and Lintermans 2012). This trend of declining ecological condition is typical worldwide (Dudgeon et al. 2006). The challenges surrounding sustainable use of water resources are likely to be further exacerbated by population growth and climate change (Aldous et al. 2011; Pittock and Finlayson 2011). 
Federal and State governments in Australia have acted to arrest declines in the ecological health of riverine systems, through the National River Health Program (1992), Council of Australia Governments water reforms (1994), the National Water Initiative (2004), the Water Act 2007 (see Australia Government 2015) and the Water for the Future program (2010) These initiatives and similar approaches worldwide require information that is best derived from a long-term and widespread program of monitoring, assessment and evaluation. Such a program should evaluate the condition of these resources as functioning aquatic ecosystems, complementing assessment of their values for agriculture, urban water supply and other human uses.

Freshwater biological assessment, or 'bioassessment', is used to quantify the ecological status of water bodies, describe change in status over time, identify progress against management targets and diagnose causes and effects of biological degradation.

Bioassessment comprises a suite of methods for surveying aquatic biota. In this paper we are referring to bioassessment approaches that measure the freshwater communities resident in a waterbody. We are not referring to the measurement of biomarkers, species physiology, biochemistry or gene expression. Describing and interpreting the changes in the composition of benthic invertebrate assemblages has been a particular focus in Australia and worldwide (e.g. Barbour et al. 1999; ANZECC and ARMCANZ 2000a; Jones et al. 2010) and is important for effective management of water resources, particularly when combined with physical and chemical monitoring (ANZECC and ARMCANZ 2000b). Bioassessment is of great value in measuring cost-effectiveness of expenditure for catchments and waterway restoration, to ensure that interventions are achieving intended ecological objectives.

In Europe, bioassessment approaches are a key component of the European Union's Water Framework Directive (WFD), a comprehensive policy framework that integrates the protection and sustainable management of surface and ground water into other areas of policy (WFD 2000). Working from the subsidiarity principle, the 28 member states of the European Union (and Norway) have worked towards harmonizing (inter-calibrating) their national bioassessment procedures, facilitating a timetable of repeat overviews of condition (status), and assessing change in condition of water bodies across Europe. The WFD provides a mandate for national policies to drive improvements in the condition of water bodies, with a target of achieving 'Good' status in all water bodies where it is feasible, and no decline in status. 
Broad-scale assessment of condition of rivers and streams often spans political and administrative boundaries, requiring multijurisdictional coordination. In Australia, the Australian River Assessment System (AUSRIVAS) bioassessment framework (Davies 2000; Simpson and Norris 2000) enabled the National River Health Program's nationwide assessment of river health (Norris et al. 2001b). These data demonstrated massive humaninduced change to Australian rivers (Norris et al. 2007). The findings informed decision making within the Australian Government and contributed to positive changes in management and investment for broad-scale, environmentally sustainable, water management. That bioassessment framework established the most spatially extensive bioassessment data set now available in Australia -a data set that has many benefits beyond its primary purpose(see Marsh et al. 2012).

Despite these broad-scale concerns for the sustainable use of water resources in Australia, investment in nationally coordinated broad-scale freshwater bioassessment has reduced over the last decade. The National River Health Program was discontinued in 2002 and national-scale monitoring ceased. The federally funded Sustainable Rivers Audit (Davies et al. 2010) of the Murray-Darling Basin has been scaled back, evolving to focus on specific ecological objectives related to environmental watering. Australian governments are increasingly applying bioassessment to shorter-term investigations or analysis of smaller-scale intervention projects. However, is this shift towards a more local perspective addressing the broad-scale, longer-term needs of our riverine ecosystems?

In this paper, we argue that to attain sustainability for freshwaters nationally in Australia it is essential to resume a nationally-coordinated program of broad-scale bioassessment so that managers have continuing and comparable information on changes in condition across whole river systems, regions and climatic zones. To encourage this reinvigoration, we start by examining the value and essential attributes of broad-scale bioassessment programs in Australia, UK/Europe, USA and Canada, and then examine new technologies that hold promise for overcoming some of the shortcomings of current bioassessment. Last, we overview a proposed approach to modernize bioassessment in Australia and to re-establish a national focus.

\section{Bioassessment, its value and uses}

Benthic invertebrates are commonly used for freshwater bioassessment because they facilitate the delivery of many ecosystem services and reflect delivery of others, while 
responding in a broadly systematic way to many human interventions. Invertebrates are food for fish and other organisms, provide ecosystem functions such as nutrient processing and retention, and carbon fixation, and are used by humans in recreation and education (Suter and Cormier 2014). Invertebrate bioassessment provides one of several possible 'windows' onto the status and functioning of freshwater ecosystems.

Bioassessment has utility to stakeholders for many reasons at all levels of governance (Table 1). Bioassessment provides a time-integrated assessment of impacts on aquatic ecosystems. Thisis effective at detecting longer-term effects of episodic events (Kowalik and Ormerod 2006; Beketov et al. 2013) and cumulative effects of chronic stressors (Liess and Beketov 2011).Bioassessment outputs can also be used to generate simple 'report cards' about waterway condition for engagement with managers, politicians and the broader community (e.g. Norris et al. 2001a; Bunn et al. 2010). Report cards can summarize complex biological information into simple 'traffic light' style representations of condition (Table 1) at various scales e.g. Australia(Harrison et al. 2011);Europe (European Commission 2012). Data on trends in indices through time over large scales can provide informative representations of effects of changes in management actions such as restoration of riparian zones, mitigation of salinization or provision of environmental flows (e.g. Thomson et al. 2012).

Effective bioassessment involves comparison to a reference condition (or 'control'). The reference condition approach (Reynoldson et al. 1997) uses a regional reference condition defined by sites in undisturbed (or minimally disturbed) condition. These methods provide a benchmark against which to judge impacts (Hawkins et al. 2010), correcting for the natural variation in environmental conditions between sites, which is often observed within broad-scale monitoring programs (Jones et al. 2010). The reference condition approach is also cost-effective for broad-scale surveillance monitoring because it enables a level of rigor and confidence in the results that can be prohibitive using a traditional 'Before After Control Impact' sampling designs and impossible (for both broad and fine-scale monitoring) when the disturbance occurred in the past. Bioassessment against a reference condition is powerful in this context because it can express quantitatively whether degradation, or recovery, is happening and how quickly.

\section{Two distinct but complementary approaches to bioassessment}


Broad-scale surveillance bioassessment and finer-scaled intervention or investigative bioassessment represent two distinct but complementary approaches. The risk of relying solely on broad-scale surveillance bioassessment is that the data will have insufficient detail to detect small changes resulting from management actions at specific locations. Focussing on bioassessment at fine scales often precludes the collection of long-term contextual data and shifts in baseline conditions could obscure responses to management actions. Moreover, sampling only for fine-scale intervention or investigative assessment may miss some impacts of unforeseen major stressors or those acting at larger scales, and also may lack the regional context within which to frame the nature of an ecological response.

\section{Australian bioassessment and water policy}

Australia currently lacks surveillance monitoring and assessment of riverine condition in many places that would allow detection of unexpected declines in river condition, and timely remediation. In the early 1990s, concern regarding broad-scale environmental events (e.g. the Darling River blue-green algal blooms of 1991; Donnelly et al. 1997) and the inclusion of biological indicators in national policy and water quality guidelines (such as ANZECC 1992) accelerated the development and implementation of bioassessment in Australia (Davies 2000). It was recognized that biological data were needed to complement chemical and physical measurements, and so improve management decisions regarding the ecological condition of Australia's rivers. Research and development activities adapted methods and indices from the UK and North America aimed at standardizing interpretation and reporting, particularly for broad-scale assessment (Chessman 1995; Marchant et al. 1997). The Australian River Assessment System (AUSRIVAS) was developed during this phase of bioassessment under the Australian Federal Government National River Health Program (NRHP) (see Davies 1994).

The NRHP involved the major environmental agency in each Australian state and territory as well as university and independent research providers, and was centrally administered by the Federal government. The objective of the program was to develop a bioassessment system that could deliver a nation-wide assessment of river health. The program resulted in just one national river health survey that included 6000 sites (Davies 2000). Since that initial assessment, no updated nationally coordinated assessment of river and stream condition has been conducted, and AUSRIVAS is now largely used for targeted site 
assessments and State or Territory-based assessment purposes.. The NRHP is now defunct but several states (but not all) have maintained the component bioassessment programs at state-wide or regional scales (over thousands of square kilometres) (Table 2). A ministerial requirement still exists under the Environment Protection and Biodiversity Conservation Act 1999 to report to Parliament every five years on the national state of the environment. However, this national State of the Environment reporting on river condition remains limited because regional assessment is not consistent temporally and the spatial coverage of sites is not adequate (Harrison et al. 2011).

The history of riverine bioassessment in Australia ranges from short-term, small-scale studies of particular issues, through to longer-term and larger-scale programs (Fig. 1). Broad-scale bioassessment data have been used for post-hoc analyses of drivers of environment concern such as climate change (e.g. Chessman 2009; Thomson et al. 2012). Some broad-scale bioassessment programs have been complemented by research projects, such as the Monitoring River Health Initiative (Davies 1994). More recent examples include assessing the effects of riparian restoration - see the Riparian Restoration Experiment (Hale et al. 2011) and Carbon Project (Giling et al. 2013). Smaller-scale research projects have been used to complement bioassessment programs (e.g. Cotter River environmental flows studies; Norris and Nichols 2011; White et al. 2012), which in some cases have extended over 5-10 years (e.g. Items 9, 10; Table 2).

Although some of the bioassessment programs referred to above and in Table 2 are at relatively large scales they are not necessarily ongoing or long-term. The current absence of programs at the broad scale and the long-term is an obvious gap (Fig. 1). This is particularly important given that changes in land and water use, and climate change, have broad-scale, cross-boundary impacts. While this is recognised in the Murray Darling Basin Plan (Commonwealth of Australia 2012), Australia currently lacks a coordinated nationwide program addressing multi-decadal impacts and responses (see Fig. 1). To detect the slower changes wrought by climate change and deal with the long response times expected for many restoration programs, a reinvigorated national-scale program is needed to address the clear bioassessment gap at the right-hand end of Figure 1. To encourage this reinvigoration, we start by examining essential attributes of broad-scale (national / multinational) bioassessment programs (again with a focus on riverine benthic invertebrates). 
226 Broad-scale (multijurisdictional) surveillance bioassessment programs face multiple

227 operational and financial challenges, as well as ensuring legacies under changing

228 administrative arrangements. These can be seen when examining the Australian

229 program alongside three other broad-scale programs.

231 Beginning in the early 1970s, the United Kingdom's bioassessment program is the oldest

232 of the four national surveillance programs considered here. The objective of this program

233 was to provide ongoing broad-scale assessment of the ecological status of rivers. Regional biological assessment programs (typically based on invertebrates and fish) were established prior to this, but they lacked comparability. To enable a UK-wide river assessment (using invertebrate data), a predictive modelling approach was developed based on reference condition, the River Invertebrate Prediction and Classification System (RIVPACS, Wright et al. 2000), initially from a reference data set of 268 sites. In 2014, after three further iterations, the data set includes 685 reference sites (Jones et al. 2010).

A major component of the program was a quinquennial national river survey, which provided reports of status and trend. In England and Wales, the first 'national' survey was of approximately 5000 river sites in 1990 by the National Rivers Authority, and similar surveillance surveys were conducted in Northern Ireland and Scotland. The surveillance surveys were repeated in 1995, then 2000 and 2005. After the adoption of the European Union's Water Framework Directive (European Parliament 2000) into UK national legislation, the surveillance monitoring program shifted to a rolling (temporally stratified) survey design with the same broad-scale objectives but approximately a third of sites sampled each year, and status and trends reported every six years using a new version of RIVPACS compliant with WFD legislation (now housed in the River Invertebrate Classification Tool). In addition, new tools were developed, based on the reference condition approach, to enable the other biological quality elements stipulated in the WFD to be included in assessments, and water bodies other than rivers to be assessed. larger monitoring network covering 29 countries across Europe and comprising more than 300 separate bioassessment systems (Birk et al. 2012; Poikane et al. 2015). This has 
required inter-calibrating bioassessment approaches across member states to ensure comparability in both the quality assessments (e.g. High, Good, Moderate, Poor, Bad) and targets. This complex process has focussed on harmonising quality class boundaries, particularly the politically important Good/Moderate boundary. In addition, member states must establish the uncertainty associated with their systems. Despite the difficulties of inter-calibration, the WFD provides a framework based on common principles for EU member states to coordinate efforts to improve the protection of water quantity and quality, to promote sustainable water use, and to help control trans-boundary water problems for surface waters.

Reporting of status and trends of water resources is now supra-national with all EU member states working to a common timetable of reporting at member state and regional level. This reporting is tied to a cyclical management framework with a common goal of all water bodies achieving 'Good' status, and no overall decline in the proportion of sites failing to achieve this between reporting periods (i.e. 2015, 2021, 2027). Failure puts the member state at risk of being subject to infraction proceedings and potentially punitive fines from the European Union. Sitting below this surveillance program, both finer-scale and investigative monitoring approaches are used to establish the cause of issues and the effectiveness of interventions designed to improve status. The long-term monitoring of British rivers show their condition has improved considerably since 1990 (DEFRA 2012).

\section{Bioassessment in Canada}

The Canadian aquatic biomonitoring network (CABIN) was developed from regional bioassessment programs for the Great Lakes (1990-1994) and the Fraser River (1993 - 1997) (Reynoldson et al. 2001). The regional success of these programs resulted in a recommendation for a national biomonitoring program (Reynoldson et al. 1999) that would:

- address environmental problems affecting large areas of the country and that have cumulative effects on freshwater ecosystems;

- meet regional requirements for biological assessment (e.g. Prairie Provinces Water Board, Ecosystem Initiatives);

- provide the needs of a national early warning system; and 
- address concerns expressed in the Office of the Auditor General / Commissioner of the Environment and Sustainable Development 1999 report that there were 'significant shortcomings in the federal government's environmental monitoring activities' and 'the federal government's approach to effects monitoring is disorganised and lacks focus' (CESD 1999).

At present, the program coverage is still patchy because it relies on collaborative participation and data sharing by multiple agencies and governments. The network currently covers most of British Columbia, the Yukon, Northern Ontario, the Great Lakes and Atlantic Canada, and has specific areas of interest in the Northwest Territories, Alberta, Saskatchewan, Manitoba, Ontario and Quebec. There is however, no substantial program of surveys and reporting on the condition of rivers and streams at the national level. The Canadian Environmental Sustainability Indicators (CESI; https://www.ec.gc.ca/indicateurs-indicators/) is a survey at selected sites around the country that reports on focused physical-chemical water quality variables but it has no bioassessment component.

\section{Bioassessment in USA}

Bioassessment in the United States is largely conducted in response to requirements of the 1972 Clean Water Act (amended in 1987) that states and tribes monitor the water quality of their surface and ground waters. The Clean Water Act was enacted to 'restore and maintain the chemical, physical, and biological integrity of the nation's waters'. Section 305(b) of the Clean Water Act requires that states report the results of their assessments to the US Environmental Protection Agency (USEPA) and that the USEPA summarizes these results in a report to Congress every two years. The intent of the national 305(b) reports was to inform Congress about trends and status of the nation's water quality, including aspects of biological integrity.

However, the 305(b) summaries have been criticized since the late 1970s for several reasons including the lack of ecologically relevant data and inconsistencies in the survey designs, methods, and criteria used by different states and tribes (GAO US 2000; Shapiro et al. 2008). In 2005, the USEPA Office of Water, in partnership with states, tribes, and the USEPA Office of Research and Development Environmental Monitoring and Assessment Program, initiated the National Aquatic Resource Surveys (USEPA 2009). These surveys are designed to provide nationally consistent and 
scientifically valid assessments of the quality of the nation's waters and the stressors associated with degradation. These assessments use probability-based survey designs, standardized sampling methods and indices to produce estimates of water quality at national, regional, and state spatial scales. The surveys are conducted for streams and rivers, lakes, coastal waters, and wetlands on a 5-year rotation with streams and rivers being surveyed over a two-year period. Biological assessments are based on both multi-metric indices and RIVPACS-type observed/expected (O/E) taxa indices.

\section{Comparative summary of national bioassessment in Australia, United Kingdom/Europe, Canada and USA}

Our assessment of the above programs identifies five attributes (Table 3) that broad-scale (national or multi-national) aquatic bioassessment programs should meet to be successful: a mandate, political context and governance, fitness for purpose, clear objectives and relevancy. Table 4 compares these programs against these attributes .We have only reviewed selected programs that involve broad spatial scales. . Other countries have developed, or are in the process of developing, broad-scale bioassessment programs e.g. South Africa (Dickens and Graham 2002), Thailand (Boonsoong et al. 2009), the Hindu Kush-Himalayan Region (Stubauer et al. 2010) and in East Africa (Masese et al. 2013). Buss et al. (2015) reviewed 13 bioassessment protocols used around the world and this suggests that our chosen programs are representative of that broader set.

The similarities and contrasts between the programs we review are instructive. All purport to be national scale (or multi-national in the case of EU) but only the UK/Europe and USA programs remain truly broad-scale multi-jurisdictional, and indications are that these two programs have the strongest political context and governance (Table 4). Spatial coverage might be considered important (or pose difficulties) in the development of a comparable broad-scale bioassessment program. Smaller countries such as the UK $\left(244,000 \mathrm{~km}^{2}\right)$ may be thought of as better suited for the approach. However, both the USA $\left(9,631,420 \mathrm{~km}^{2}\right)$ and the European Union $\left(4,422,773 \mathrm{~km}^{2}\right)$ are committed to broad-scale aquatic bioassessment programs not matched by Australia $\left(7,682,000 \mathrm{~km}^{2}\right)$ or Canada $\left(9,984,670 \mathrm{~km}^{2}\right)$, despite their similar land areas and variation in environmental conditions.

In the early political development of both Canada and Australia constitutional transfer of resource management powers to the regions (provinces and states / territories 
respectively) was a consequence of their large area. This structure has reduced the federal (national) role in resource management and tends to drive a piecemeal approach to broad-scale problems. In Australia, one consequence of this was that the national program was built on existing state programs and the capacity to take advantage of higher spatial scale incorporation may have been compromised (a Framework for the Assessment of River and Wetland Health was subsequently developed to overcome this very issue, see Alluvium Consulting 2011). In contrast, resource management in the UK was devolved to the home nations with separate legislation and structures in Northern Ireland and Scotland, yet from this disparate network a coordinated program developed. In turn, this has been replaced by a European framework covering all member states where, working from a principal of subsidiarity, the reporting of national programs has been synchronised to produce a system capable of delivering supra-national goals. Although the process of intercalibration is challenging and time consuming, it is evident that a federal/state structure does not preclude consistent broad-scale reporting. In terms of temporal (and political) continuity there are advantages to incorporating established state monitoring systems into a broad-scale network, but these advantages have to be weighed against the effort required (and uncertainty incorporated) when doing so.

National aquatic bioassessment programs in the UK, USA, and initially in Australia, had strong political and/or policy mandates and were developed in response to public concerns and requests from national and state agencies. The mandates have continued to evolve in the UK, Europe and USA. In Australia's case, the national program was developed in response to a perceived crisis and not sustained over the long term. The initial strong impetus for a national assessment of river health has been weakened by a changing federal context, continual jurisdictional re-organisations and a lack of a consistent national policy focus for non-marine aquatic ecosystem management. Australian riverine bioassessment programs are now serving only state, regional and local needs. In Canada, there was never a management or political requirement for national freshwater bioassessment. Canada's national program and methods were developed from regional projects or initiatives rather than a diverse array of provincial programs. In that sense, the CABIN program was driven from the bottom up to meet a need that was not acknowledged at higher levels of Government. It seems that without a strong policy driving the need for broad-scale bioassessment, the default is smaller 
scale and local assessments that target specific interventions. Without coordination, bioassessment at this scale may not produce data that can be aggregated to meet national reporting and/or policy needs, and may not necessarily align with the broadscale, longer-term needs of our riverine ecosystems.

In Australia, new challenges are restricting applications of bioassessment. With some bioassessment techniques currently in use, practitioners cannot readily diagnose the causes of impairment or place the scale of impairment in a broader context (Nichols and Dyer 2013). Another challenge relates to unrealistic expectations of the time needed to measure an ecological response to interventions, which presents a challenge within short political cycles. Actual ecological responses may be slow and must be assessed against a background of natural variability. Broad-scale assessments require considerable effort, coordination and spatial coverage, all of which take time and resources (Tullos et al. 2009). Emerging techniques could help address some of these challenges. However, the capacity of bioassessment in general, and particularly of broad-scale and coordinated long-term programs, will continue to be restricted unless policies and resourcing are focused on emerging water management needs and the uptake of emerging technologies.

\section{Emerging technologies}

A range of emerging technologies and approaches could help improve the efficiency of bioassessment and its suitability to meet the challenges of current bioassessment and future broad-scale programs.

\section{Molecular tools}

The rapid development of molecular techniques for taxonomic identification, along with associated advancement in methods for data generation and analysis, has made molecular analyses both fast and cost-effective (Shokralla et al. 2012). High throughput molecular methods and next generation sequencing (NGS) technology can potentially increase the accuracy, speed and reduce the costs of the sample sorting and identification. DNA barcoding uses a short DNA sequence from a specified region of the genome to provide an identity 'barcode'. The application of molecular techniques to biomonitoring and the assessment of aquatic ecosystem condition is at the forefront of the technology (Baird and Hajibabaei 2012; Deiner et al. 2015). DNA barcoding can reliably identify species 
regardless of life-stage or damage to the specimen, and was found to reveal more insect 'species' with greater accuracy than traditional methods (Dapkey 2008). Additionally, while traditional bioassessment methods target a single group of organisms, e.g. macroinvertebrates, molecular approaches could collect data on other biotic groups such as algae and microbial communities, which may offer further insights into ecological processes (Woodward et al. 2013).

The opportunity now exists to develop broad-scale bioassessment that is more efficient (in time and cost). This should further facilitate community or 'citizen science' bioassessment programs that are currently hindered by lack of taxonomic expertise (Biggs et al. 2015).

Samples could be collected by trained community members and sent to specialist laboratories to produce species lists and provide other benefits, such as a faster sample processing and increased taxonomic resolution compared with traditional morphological identifications (Stein et al. 2014). This could facilitate community engagement and extend a national bioassessment network.

Work has begun on DNA barcoding for use in freshwater bioassessment (Hajibabaei et al. 2011; Carew et al. 2013) but we need to demonstrate the value of integrating these new approaches and emerging technologies with existing bioassessment frameworks for broadscale monitoring (Pilgrim et al. 2011). This requires fundamental research to avoid introducing new errors (for further discussion see Dafforn et al. 2015).

\section{Diagnostic bioassessment and linking bioassessment with ecosystem services}

The pioneers of bioassessment have always stressed the importance of integrating biological information with data from habitat assessments, hydrological investigations, and knowledge of land use to aid interpretation of biological data and to provide a more comprehensive diagnostic assessment of impacts (Norris and Norris 1995; Barbour et al. 1999; Karr 1999). Bioassessment is important in this sense because (a) the sampling regime of routine physical and chemical sampling is seldom adequate to describe temporal variation in the levels of many stressors (e.g. turbidity, pesticides) and cannot detect stressors that are not specifically targeted for measurement; and (b) without bioassessment the ecological impacts of particular stressors or combinations of stressors may be simply inferred. Management could be greatly improved with methods and tools for better understanding the causes of ecological degradation. Improving the diagnostic capacity of 
bioassessment is recognised as a priority area for research and development (Jones et al. 2010; Murphy et al. 2013).

Variation in the traits (characteristics) of stream invertebrates is showing renewed promise for diagnosing likely causes of reduced ecological condition (Statzner and Beche 2010; Schafer et al. 2011). Indeed, the inclusion of evaluations of invertebrate traits (e.g. sensitive taxonomic groups, functional feeding groups) and interpretation of results based on the knowledge of invertebrate ecology is not a new concept for bioassessment (Barbour et al. 1999). Stream invertebrate traits can include body size, life-span, dispersal characteristics, respiration mode and feeding mechanism. However, linking traits to environmental conditions in a consistent and generalised way requires further research to provide the mechanistic understanding of species-environment relationships (Pilière et al. 2015). The challenge is then to harness this knowledge to develop tools so that trait information is more easily understood by bioassessment practitioners, and thus aid diagnostic interpretation of biological data. Importantly, such trait information could be applied to existing bioassessment data sets to allow the retrospective use of trait-based assessments.

Ecosystem services are increasingly a focus of global conservation and restoration efforts (Aylward et al. 2005). Once research has established relationships between aspects of water quality and the traits of invertebrates (and other biological groups), the way will be open for linking broad-scale measures of biological degradation (i.e. bioassessment results based on the structure of fauna assemblage) to the corresponding consequences for ecosystem functions or services. At present those links are not always clear (Tolonen et al. 2014) and this is an area for improvement in bioassessment. Moreover, as molecular studies advance over the next decade, functional genes associated with suites of taxa will be identified, thus further facilitating direct assessment of ecosystem functional consequences using molecular analysis of samples collected for bioassessment.

\section{Shifting baselines}

One of the challenges for bioassessment programs is dealing with broad-scale, longer-term changes in environmental conditions, most notably in response to climate change. Changes in baseline conditions mean that bioassessment approaches that rely on reference conditions need to account for changes in the reference conditions themselves as a consequence climatic alterations. Research has identified cases where longer-term trends 
477 in reference site condition suggest that sites do remain within a stable reference condition

478 (Metzeling et al. 2002; Nichols et al. 2010) and the concordance of a reference site to a

479 reference group in predictive models appears robust for those environments, and at those

480 spatial and temporal scales and taxonomic level studied. However, these encouraging

481 relationships may not persist as climate change intensifies, so further review and validation

482 is urgently needed (Reynoldson and Wright 2000), particularly where the long-term

483 temporal and spatial variability are high (e.g. in Australia) (Barmuta et al. 2003).

484 With appropriate consideration of site selection, bioassessment programs with long-term

485 data on reference conditions should enable the description of long-term trends in

486 ecological condition as a consequence of changing climate and other slow environmental

487 changes (e.g. salinization, changes in catchment land cover). Combining these insights

488 with modern statistical approaches, GIS and remote sensing tools can allow a detailed

489 understanding of the effects of climate and its interactions with multiple impacts on

490 ecological condition (Thomson et al. 2012; Dafforn et al. 2015).

491 Strategies for modernizing freshwater bioassessment in Australia

492 The attributes of successful large regional or national scale bioassessment programs can be

493 further examined to elaborate strategies to modernize freshwater bioassessment in

494 Australia and re-establishing a national broad-scale focus.

\section{The mandate}

496 Management of water resources should be based on timely policy decisions supported by

497 an informed and updated understanding of the national position. Reactive management,

498 once a crisis has developed, is typically expensive and difficult. Among the many

499 competing demands on federal government in Australia, the political mandate for state-of-

500 the-nation assessment of rivers and an adequate sentinel system lacks a national policy

501 driver and legislative backing. Hence, no mechanism currently exists to establish the

502 national position regarding riverine ecosystems and changes in the condition of these

503 resources. We recommend the convening of a summit of policy makers, key stakeholders

504 and scientists to develop strategies and priorities for riverine protection and conservation.

505 In the absence of a broad-scale environmental crisis like the 1991 algal bloom on the

506 Darling River, another prospect for creating a sustained national mandate for freshwater 
507

508

509

510

511

512

513

514

515

516

517

518

519

520

521

522

523

524

525

526

527

528

529

530

531

532

533

534

535

536

537

bioassessment is to capitalize on public concern for good environmental stewardship. This requires 'bottom-up' pressure for a national approach from diverse, widely dispersed and informed stakeholders who are concerned about riverine health. Coherently harnessing the concerns of the broader community into a national voice, perhaps connected through social media and the internet (e.g. eWater community - www.ewater.com.au/community), could provide an opportunity to drive a more enduring mandate, in contrast to disjointed responses to erupting environmental crises.

\section{Political context and governance}

In the USA and Europe, river health assessment programs are legislated and have an appointed government agency to take responsibility for delivering the programs. With such responsibility comes necessary governance, which includes setting of program targets, identifying key indicators of assessment, monitoring, restoration, establishing measurement endpoints of success and coordination, planning, funding (with cost sharing as appropriate) and public reporting of progress.

The national focus on measuring the ecological and physico-chemical quality of freshwater resources in Australia has given way to regional and jurisdictional foci, which lack coordination across borders. If the general community could set a national mandate for river health assessment through 'bottom-up' pressure for 'good quality' riverine ecosystems, then community-run assessment programs (e.g. Waterwatch) would have the potential to operate and be governed in a more nationally coordinated fashion. An emphasis on the different values of river health, such as recreation (e.g. fishers), aesthetics (e.g. real estate agents and property investors) and biodiversity (e.g. horticultural groups) could help to strengthen this pressure. Attention would need to be paid to principles that tailor bioassessment for targeted management, while at the same time generating data for reuse and aggregation to meet management objectives across several spatial and temporal scales (e.g. as developed for the Framework for the Assessment of River and Wetland Health; Alluvium Consulting 2011).

\section{Fit for purpose and clear objectives}

A driver for bioassessment, monitoring and evaluation is the presence of well-defined and measurable ecological objectives for management instruments and policies. Bioassessment objectives can range from tracking trends in ecological condition through time, to 
diagnosing the causes of impairment and gauging the success of mitigation activities. At state or smaller regional scales, these latter objectives may take greater priority at times. Such data may not be suitable for national-scale assessment if the data cannot be aggregated in a way to detect trends at that larger spatial scale.

Well-crafted 'SMART' (specific, measurable, achievable, relevant and timed) ecological objectives are rare in the policy and regulatory sphere. When present they quantify the social vision of the desired future state of the ecosystem, while driving the need for bioassessment to provide 'measures of success' of management investment. This need was addressed in the Murray Darling Basin Watering Strategy (MDBA 2014), which contains a number of quantified ecological outcomes against which to report the condition of the Basin river system. Development of quantified ecological outcomes at national scales, though challenging, would help define the need for a national bioassessment effort.

'Critical elements' that determine whether a bioassessment program is 'fit for purpose' include its study design, and an understanding of the uncertainty and comparability of the collected data. These aspects are important for integrating and aggregating results from different programs for use in broader-scale assessments e.g. national State of the Environment reporting. For example, Yoder and Barbour (2009) applied the US critical elements guidelines (USEPA 2013) for assessing the level of technical rigor of USA bioassessment programs. As an example in Australia, the Framework for the Assessment of River and Wetland Health (FARWH) was designed to aggregate results from disparate monitoring programs that shared critical elements (Alluvium Consulting 2011).

Important features of the FARWH included the ability to report the variables measured at sample sites as departure from a reference condition, and that all the indicators used could be mapped to one of seven super-indices - i.e. catchment disturbance, hydrological disturbance, water quality and soils, physical form, fringing zone, aquatic biota and (if the sample was from a wetland) wetland extent - which allowed comparisons of condition between regions. Where approaches differ, benchmarking exercises can establish comparability, for example the inter-calibration between the national approaches in Europe. Likewise, the critical elements principles (e.g. Yoder and Barbour 2009) must also be applied to bioassessment of local, targeted management interventions; otherwise a perceived lack of biological response may be misinterpreted by practitioners. The consequences of using various bioassessment approaches and design options need to be 
570

571

572

573

574

575

576

577

578

579

580

581

582

583

584

585

586

587

588

589

590

591

592

593

594

595

596

597

598

599

600

understood, particularly if the data are to be used for multiple purposes. Such understanding could be achieved through guidelines for best bioassessment practice and practitioner certification.

\section{Currency and relevance}

Tables 1 and 2 provide examples of the value of bioassessment for evaluating water quality and the ecological health of riverine ecosystems. To keep bioassessment current and relevant, two distinct avenues of research are required. One aims to make bioassessment more cost effective and useful in terms of diagnostic and other information, and investigates emerging technologies as outlined above. The second, needs to promote bioassessment as a social and business process, and would investigate topics such as:

- how bioassessment creates value for the stakeholders (as in Table 1) and how the needs of different businesses and stakeholders vary and intersect;

- how various stakeholder interactions might add value, particularly how to combine and maximize returns from 'bottom up' community-driven bioassessment, and 'top-down' government led programs, and how stakeholders might be productively engaged; and

- what methods can be used to identify common concerns from within a multiplicity of local community inputs, to help create a national mandate for river health and bioassessment.

The water sector is constantly evolving and, once initiated, these avenues of research need to continue if bioassessment methods are to be kept relevant to practitioners. In addition, adoption at a national level of new and integrated approaches active at regional scales should be encouraged.

\section{Implementation of the modernization strategies}

We propose that riverine bioassessment in Australia needs modernizing to meet the evolving needs of practitioners and other stakeholders to achieve more effective outcomes, and to support a nationally coordinated program that addresses the broad-scale, longerterm needs of our freshwater ecosystems. There are three distinct stages for implementing the strategies outlined above (e.g. Fig. 2). In overview, these stages include initial tasks, subsequent tasks and strategies that must be funded to be fully realised. Initially, the emphasis is on planning, promotion, and establishing core resources, while later efforts are 
601

602

603

604

605

606

607

608

609

610

611

612

613

614

615

616

617

618

619

620

621

622

623

624

625

626

627

628

629

630

631

632

focussed on 'doing', particularly once funding is secured, although later iteration between stages will be inevitable. For example, promotion of the benefits of broad-scale bioassessment is vital initially but also required periodically to energise and refocus. The audience for this plan includes researchers (from government, universities, industry bodies and research organizations), community champions and water industries, other nongovernment organizations, and other end-users of bioassessment information (see Table 1).

It is important to avoid 'reinventing the wheel' and to be adaptive by building on the significant investments already made in developing bioassessment programs by State, Territory and Federal governments. FARWH exemplified this in Australia. It was designed to enable data collected from existing monitoring and assessment programs to be incorporated into a nationally comparable reporting framework. Subsequently, five options were outlined for the staged implementation of river health assessment based on increasing resources, scope and extent of coverage across catchments (see Alluvium Consulting 2011) and that experience could provide a starting template for scaling modernization of bioassessment from regional through to national levels.

\section{Conclusions}

Bioassessment in Australia has advanced a long way in the last 30 years and provides benefits to many stakeholders. However, even with the federally-led water reforms in Australia over that period, a nationally focused bioassessment program lacks a high priority policy driver, which is in stark contrast to the USA and UK/EU situation. A reinvigoration and modernization strategy for bioassessment is needed to avoid the risk of losing relevance and currency, and to facilitate a nationally coordinated bioassessment program to address the broad-scale, longer-term needs of riverine ecosystems. Research has contributed greatly to other national and global efforts in freshwater bioassessment. Australia has the expertise and capability to build on this knowledge and implement a modernized bioassessment program on a national scale. Modernization strategies should not be designed assuming bioassessment professionals will abandon their current practices in favour of others deemed better. Most jurisdictions will favour 'adaptive' investment that builds on existing capacity and methods.

We recommend the following steps to improve bioassessment practice in Australia: (1) convene a summit of policy makers and key scientists; (2) develop strategies and priorities for riverine protection and conservation; (3) identify key indicators of assessment, 
633 monitoring, restoration, and conservation; (4) establish measurement endpoints of success

634 and identify expertise; and (5) develop a plan forward for implementation and coordination

635 that involves both 'bottom up' community-driven bioassessment and 'top-down'

636 government led programs.

637 An approach to facilitate improved bioassessment practices should integrate lessons

638 learned and emerging technologies, and ultimately form the basis for a mature professional

639 climate where ongoing research, training and accreditation are normal aspects of

640 professional practice. If much, or even all, of this can be achieved then it should become

641 much easier for bioassessment practitioners to coordinate local, regional and national

642 activities.

643 Acknowledgements

644 We acknowledge the pioneering efforts of the late Professor Richard Norris who initiated

645 much of the AUSRIVAS work and his major contributions to national bioassessment of

646 river condition in Australia. This paper was an outcome of the International Aquatic Health

647 and Management Symposium, Canberra 2013 hosted by the Institute for Applied Ecology

648 at the University of Canberra, the Murray-Darling Basin Futures Collaborative Research

649 Network and eWater. RT was funded by an ARC Future Fellowship FT110100957. SL is

650 funded by an ARC DECRA grant DE130100565. We also acknowledge 2 anonymous

651 referees who generously contributed their time and effort. Their recommendations greatly

652 enhanced the value of this manuscript. 
Aldous, A., Fitzsimons, J., Richter, B., and Bach, L. (2011). Droughts, floods and freshwater ecosystems: evaluating climate change impacts and developing adaptation strategies. Marine and Freshwater Research 62, 223-231.

Alluvium Consulting (2011). Framework for the assessment of river and wetland health: findings from the trials and options for uptake, Waterlines report Series No 58, September 2011. National Water Commission, Canberra. Available at http://www.nwc.gov.au/_data/assets/pdf_file/0019/18631/FARWH-WaterlinesFINALV3_2209.pdf [accessed 3 August 2015].

ANZECC (1992). Australian water quality guidelines for fresh and marine waters. National water quality management strategy. Australian and New Zealand Environment and Conservation Council, Canberra.

ANZECC, and ARMCANZ (2000a). Australian and New Zealand Guidelines for Fresh and Marine Water Quality. National water quality management strategy. Australian and New Zealand Environment and Conservation Council and the Agriculture and Resource Management Council of Australia and New Zealand.

ANZECC, and ARMCANZ (2000b). Australian Guidelines for Water Quality Monitoring and Reporting. Section 3.5.3 pp.3-23 - 3-33; Appendix 3 Sections A.3.4, A.3.5, pp. A3-5 - A3-11.

Australia Government (2015). 'Water Act 2007 Series.' Available at https://www.comlaw.gov.au/Series/C2007A00137 [Accessed 31 July 2015].

Aylward, B., Bandyopadhyay, J., Belausteguigotia, J., Borkey, P., Cassar, A., Meadors, L., Saade, L., Siebentritt, M., Stein, R., Tognetti, S., Tortajada, C., Allan, T., Bauer, C., Guimaraes-Pereira, A., Kendall, M., Kiersch, B., Landry, C., Mestre Rodriguez, E., Meinzen-Dick, R., Moellendorg, S., Pagiola, S., Porras, I., Ratner, B., Shea, A., Swallow, B., Thomich, T., and Voutchkov, N. (2005). Freshwater Ecosystem Services. In 'Ecosystems and human well-being: policy responses, Millennium Ecosystem Assessment'. Vol. 3. (Eds. K. Chopra, R. Leemans, P. Kumar and H. Simons) pp. 213-255. (Island Press: Washington)

Baird, D. J., and Hajibabaei, M. (2012). Biomonitoring 2.0: a new paradigm in ecosystem assessment made possible by next-generation DNA sequencing. Molecular Ecology 21, 2039-2044.

Barbour, M. T., Gerritsen, J., Snyder, B. D., and Stribling, J. B. (1999). Rapid Bioassessment Protocols for Use in Streams and Wadeable Rivers: Periphyton, Benthic Macroinvertebrates and Fish, Second Edition. EPA 841-B-99-002. U.S. Environmental Protection Agency; Office of Water, Washington, D.C.

Barmuta, L. A., Emmerson, L., and Otahal, P. (2003). The sensitivity of AusRivAS to variations of input values, low natural diversity, and temporal variation. Environment Australia, Australian Capital Territory, Australia. Available at http://www.environment.gov.au/resource/sensitivity-ausrivas-variations-inputvalues-low-natural-diversity-and-temporal-variation [accessed 3 August 2015].

Beketov, M. A., Kefford, B. J., Schafer, R. B., and Liess, M. (2013). Pesticides reduce regional biodiversity of stream invertebrates. Proceedings of the National Academy of Sciences of the United States of America 110, 11039-11043.

Biggs, J., Ewald, N., Valentini, A., Gaboriaud, C., Dejean, T., Griffiths, R. A., Foster, J., Wilkinson, J. W., Arnell, A., Brotherton, P., Williams, P., and Dunn, F. (2015). Using eDNA to develop a national citizen science-based monitoring programme for the great crested newt (Triturus cristatus). Biological Conservation 183, 19-28. 
Birk, S., Bonne, W., Borja, A., Brucet, S., Courrat, A., Poikane, S., Solimini, A., van de Bund, W. V., Zampoukas, N., and Hering, D. (2012). Three hundred ways to assess Europe's surface waters: An almost complete overview of biological methods to implement the Water Framework Directive. Ecological Indicators 18, 31-41.

Boonsoong, B., Sangpradub, N., and Barbour, M. T. (2009). Development of rapid bioassessment approaches using benthic macroinvertebrates for Thai streams. Environmental Monitoring and Assessment 155, 129-147.

Bunn, S. E., Abal, E. G., Smith, M. J., Choy, S. C., Fellows, C. S., Harch, B. D., Kennard, M. J., and Sheldon, F. (2010). Integration of science and monitoring of river ecosystem health to guide investments in catchment protection and rehabilitation. Freshwater Biology 55, 223-240.

Buss, D. F., Carlisle, D. M., Chon, T., Culp, J., Harding, J. S., Keizer-Vlek, H. E., Robinson, W. A., Strachan, S., Thirion, C., and Hughes, R. M. (2015). Stream biomonitoring using macroinvertebrates around the globe: a comparison of largescale programs. Environmental Monitoring and Assessment 187, 1-21.

Carew, M. E., Pettigrove, V. J., Metzeling, L., and Hoffmann, A. A. (2013). Environmental monitoring using next generation sequencing: rapid identification of macroinvertebrate bioindicator species. Frontiers in Zoology 10, 1-15.

CESD (1999). 'Report of the Commissioner of the Environment and Sustainable Development. Chapter 3-Understanding the Risks From Toxic Substances: Cracks in the Foundation of the Federal House.' Available at http://www.oagbvg.gc.ca/internet/English/parl_cesd_199905_03_e_10169.html\#0.2.2Z141Z1.NB S3AG.98WQBF.J1 [accessed 18 March 2015].

Chessman, B. C. (1995). Rapid assessment of rivers using macroinvertebrates: a procedure based on habitat-specific sampling, family level Identification and a biotic index. Australian Journal of Ecology 20, 122-129.

Chessman, B. C. (2009). Climatic changes and 13-year trends in stream macroinvertebrate assemblages in New South Wales, Australia. Global Change Biology 15, 27912802.

Commonwealth of Australia (2012). Water Act 2007. Basin Plan. Australian Government, Canberra, $245 \mathrm{pp}$.

Dafforn, K. A., Johnston, E. L., Ferguson, A., Humphrey, C., Monk, W., Nichols, S. J., Simpson, S. L., Tulbure, M. G., and Baird, D. J. (2015). Big data opportunities and challenges for assessing multiple stressors across scales in aquatic ecosystems. Marine and Freshwater Research DOI: 10.1071/MF15108.

Dapkey, T. (2008). Combining DNA barcoding and macroinvertebrate sampling to assess water quality. PhD Thesis, University of Pennsylvania, Philadelphia.

Davies, P. E. (1994). 'River Bioassessment Manual Version 1.0 National River Processes and Management Program Monitoring River Health Initiative.' Available at http://www.environment.gov.au/system/files/resources/0e33f53e-4be9-4f57-87bb2200e573357d/files/bioassess.pdf [accessed 3 August 2015].

Davies, P. E. (2000). Development of a national river bioassessment system (AUSRIVAS) in Australia. In 'Assessing the Biological Quality of Fresh Waters: RIVPACS and Other Techniques'. (Eds. J. F. Wright, D. W. Sutcliffe and M. T. Furse) pp. pp 113124. (Freshwater Biological Association: Ambleside, UK)

Davies, P. E., Harris, J. H., Hillman, T. J., and Walker, K. F. (2010). The Sustainable Rivers Audit: assessing river ecosystem health in the Murray-Darling Basin, Australia. Marine and Freshwater Research 61, 764-777.

DEFRA (2012). 'Department for Environment, Food and Rural Affairs. Biological river water quality.' Available at http://www.defra.gov.uk/statistics/environment/inlandwater/iwfg08-biorivqual/ [accessed 3 August 2015]. 
Deiner, K., Walser, J. C., Machler, E., and Altermatt, F. (2015). Choice of capture and extraction methods affect detection of freshwater biodiversity from environmental DNA. Biological Conservation 183, 53-63.

Dickens, C. W. S., and Graham, P. M. (2002). The South African Scoring System (SASS) version 5 rapid bioassessment method for rivers. African Journal of Aquatic Science 27, 1-10.

Donnelly, T. H., Grace, M. R., and Hart, B. T. (1997). Algal blooms in the DarlingBarwon River, Australia. Water, Air, and Soil Pollution 99, 487-496.

Dudgeon, D., Arthington, A. H., Gessner, M. O., Kawabata, Z. I., Knowler, D. J., Leveque, C., Naiman, R. J., Prieur-Richard, A. H., Soto, D., Stiassny, M. L. J., and Sullivan, C. A. (2006). Freshwater biodiversity: importance, threats, status and conservation challenges. Biological Reviews 81, 163-182.

European Commission (2012). Report from the commission to the European Parliament and the Council on the implementation of the Water Framework Directive (2000/60/EC) River Basin Management Plans. COM670 final. European Union. Brussels, Belgium [accessed 19/08/2015 http://eur-lex.europa.eu/legalcontent/EN/TXT/PDF/?uri=CELEX:52012DC0670\&from=EN].

European Parliament (2000). Parliament and Council Directive 2000/60/EC. Establishing a framework for community action in the field of water policy. Official Journal PECONS 3639/1/00 REV 1. European Union. Brussels, Belgium.

GAO US (2000). Water quality: key EPA and state decisions limited by inconsistent and incomplete data. GAO/RCED-00-54. US General Accounting Office (now Government Accountability Office). (Washington, DC)

Giling, D., Grace, M., Mac Nally, R., and Thompson, R. M. (2013). The influence of native replanting on stream ecosystem metabolism in a degraded landscape: can a little vegetation go a long way? . Freshwater Biology 58, 2601-2613.

Hajibabaei, M., Shokralla, S., Zhou, X., Singer, G. A. C., and Baird, D. J. (2011). Environmental Barcoding: A Next-Generation Sequencing Approach for Biomonitoring Applications Using River Benthos. Plos One 6, e17497.

Hale, R., Reich, P., Lake, P. S., Thomson, J., Williams, L., Cavagnaro, T., Johnson, M., and Daniel, T. (2011). Assessing ecological indicators for monitoring responses to riparian restoration in lowland streams of the southern Murray-Darling Basin. Report to the Murray Darling Basin Commission. Canberra.

Harrison, E. T., Nichols, S., Gruber, B., Dyer, F., Tschierschke, A., and Norris, R. (2011). AUSRIVAS: Australia's in-stream biological health 2003-2010. 2011 State of the Environment reporting. Report prepared for The Australian Government, Department of Sustainability, Environment, Water, Population and Communities, Canberra.

Hawkins, C. P., Olson, J. R., and Hill, R. A. (2010). The reference condition: predicting benchmarks for ecological and water-quality assessments. Journal of the North American Benthological Society 29, 312-343.

Jones, J. I., Davy-Bowker, J., Murphy, J. F., and Pretty, J. L. (2010). Ecological monitoring and assessment of pollution in rivers. In 'Ecology of industrial pollution '. (Eds. L.C. Batty and K. B. Hallberg) pp. 126-146. (Cambridge University Press: Cambridge)

Karr, J. R. (1999). Defining and measuring river health. Freshwater Biology 41, 221-234.

Koehn, J. D., and Lintermans, M. (2012). A strategy to rehabilitate fishes of the MurrayDarling Basin, south-eastern Australia. Endangered Species Research 16, 165-181.

Kowalik, R. A., and Ormerod, S. J. (2006). Intensive sampling and transplantation experiments reveal continued effects of episodic acidification on sensitive stream invertebrates. Freshwater Biology 51, 180-191. 
Liess, M., and Beketov, M. (2011). Traits and stress: keys to identify community effects of low levels of toxicants in test systems. Ecotoxicology 20, 1328-1340.

Marchant, R., Hirst, A., Norris, R. H., Butcher, R., Metzeling, L., and Tiller, D. (1997). Classification and prediction of macroinvertebrate assemblages from running waters in Victoria, Australia. Journal of the North American Benthological Society 16, 664-681.

Marsh, N., Sheldon, F., Wettin, P., Taylor, C., and Barma, D. (2012). Guidance on ecological responses and hydrological modelling for low-flow water planning. Waterlines number 76. National Water Commission. Canberra.

Masese, F. O., Omokoto, J. O., and Nyakeya, K. (2013). Biomonitoring as a prerequisite for sustainable water resources: a review of current status, opportunities and challenges to scaling up in East Africa. Ecohydrology and Hydrobiology 13, 173191.

MDBA (2014). Basin-wide environmental watering strategy. Murray Darling Basin Authority, Canberra. November 2014. 112 pp.

Metzeling, L., Robinson, D., Perriss, S., and Marchant, R. (2002). Temporal persistence of benthic invertebrate communities in south-eastern Australian streams: taxonomic resolution and implications for the use of predictive models. Marine and Freshwater Research 53, 1223-1234.

Murphy, J. F., Davy-Bowker, J., McFarland, B., and Ormerod, S. J. (2013). A diagnostic biotic index for assessing acidity in sensitive streams in Britain. Ecological Indicators 24, 562-572.

Nichols, S. J., and Dyer, F. J. (2013). Contribution of national bioassessment approaches for assessing ecological water security: an AUSRIVAS case study. Frontiers of Environmental Science \& Engineering 7, 669-687.

Nichols, S. J., Robinson, W. A., and Norris, R. H. (2010). Using the reference condition maintains the integrity of a bioassessment program in a changing climate. Journal of the North American Benthological Society 29, 1459-1471.

Norris, R., and Nichols, S. (2011). Environmental flows: achieving ecological outcomes in variable environments. In 'Water Resources Planning and Management'. (Eds. Q. Grafton and K. Hussey) pp. 331-349. (Cambridge University Press)

Norris, R. H., Linke, S., Prosser, I., Young, W. J., Liston, P., Bauer, N., Sloane, N., Dyer, F., and Thoms, M. (2007). Very-broad-scale assessment of human impacts on river condition. Freshwater Biology 52, 959-976.

Norris, R. H., Liston, P., Davies, N., Coysh, J., Dyer, F., Linke, S., Prosser, I., and Young, B. (2001a). Snapshot of the Murray-Darling Basin River Condition. MurrayDarling Basin Commission, Canberra. 60 pp. ISBN 1876830220 Murray-Darling Basin Commission, Canberra.

Norris, R. H., and Norris, K. R. (1995). The Need for Biological Assessment of WaterQuality - Australian Perspective. Australian Journal of Ecology 20, 1-6.

Norris, R. H., Prosser, I., Young, B., Liston, P., Bauer, N., Davies, N., Dyer, F., Linke, S., and Thoms, M. (2001b). The Assessment of River Condition (ARC). An audit of the ecological condition of Australian Rivers. Final report submitted to the National Land and Water Resources Audit Office, Canberra, Australia. Available at http://iae.canberra.edu.au/reprints/2001_Norris_etal_The_assessment_of_river_con dition.pdf [accessed 23 March 2015].

Pilgrim, E. M., Jackson, S. A., Swenson, S., Turcsanyi, I., Friedman, E., Weigt, L., and Bagley, M. J. (2011). Incorporation of DNA barcoding into a large-scale biomonitoring program: opportunities and pitfalls. Journal of the North American Benthological Society 30, 217-231. 
Pilière, A. F. H., Verberk, W. C. E. P., Gräwe, M., Breure, A. M.,, Dyer, S. D., Posthuma, L., de Zwart, D., Huijbregts, M. A. J., and Schipper, A. M. (2015). On the importance of trait interrelationships for understanding environmental responses of stream macroinvertebrates. Freshwater Biology.

Pittock, J., and Finlayson, C. M. (2011). Australia's Murray-Darling Basin: freshwater ecosystem conservation options in an era of climate change. Marine and Freshwater Research 62, 232-243.

Poikane, S., Birk, S., Bohmer, J., Carvalho, L., de Hoyos, C., Gassner, H., Hellsten, S., Kelly, M., Solheim, A. L., Olin, M., Pall, K., Phillips, G., Portielje, R., Ritterbusch, D., Sandin, L., Schartau, A. K., Solimini, A. G., van den Berg, M., Wolfram, G., and van de Bund, W. (2015). A hitchhiker's guide to European lake ecological assessment and intercalibration. Ecological Indicators 52, 533-544.

Reynoldson, T. B., Bombardier, M., Donald, D., O'Neill, H. J., Rosenberg, D. M., Shear, H., Tuominen, T., and Vaughan, H. (1999). Strategy for a Canadian Aquatic Biomonitoring Network. NWRI Contribution Number. 99-248.

Reynoldson, T. B., Norris, R. H., Resh, V. H., Day, K. E., and Rosenberg, D. M. (1997). The reference condition: a comparison of multimetric and multivariate approaches to assess water-quality impairment using benthic macroinvertebrates. Journal of the North American Benthological Society 16, 833-852.

Reynoldson, T. B., Rosenberg, D. M., and Resh, V. H. (2001). Comparison of models predicting invertebrate assemblages for biomonitoring in the Fraser River catchment, British Columbia. Canadian Journal of Fisheries and Aquatic Sciences 58, $1395-1410$.

Reynoldson, T. B., and Wright, J. F. (2000). The Reference Condition: problems and solutions. In 'Assessing the biological quality of freshwaters. RIVPACS and other techniques'. (Eds. J. F. Wright, D. W. Sutcliffe and M. T. Furse) pp. pp 293-304. (Freshwater Biological Association: Ambleside, UK)

Schafer, R. B., Pettigrove, V., Rose, G., Allinson, G., Wightwick, A., von der Ohe, P. C., Shimeta, J., Kuhne, R., and Kefford, B. (2011). Effects of Pesticides Monitored with Three Sampling Methods in 24 Sites on Macroinvertebrates and Microorganisms. Environmental Science \& Technology 45, 1665-1672.

Shapiro, M. H., Holdsworth, S. M., and Paulsen, S. G. (2008). The need to assess the condition of aquatic resources in the US. Journal of the North American Benthological Society 27, 808-811.

Shokralla, S., Spall, J. L., Gibson, J. F., and Hajibabaei, M. (2012). Next-generation sequencing technologies for environmental DNA research. Molecular Ecology 21, 1794-1805.

Simpson, J. C., and Norris, R. H. (2000). Biological assessment of river quality: development of AUSRIVAS models and outputs. In 'Assessing the Biological Quality of Fresh Waters: RIVPACS and Other Techniques'. (Eds. J. F. Wright, D. W. Sutcliffe and M. T. Furse) pp. 125-142. (Freshwater Biological Association: Ambleside, Cumbria, U.K)

Statzner, B., and Beche, L. A. (2010). Can biological invertebrate traits resolve effects of multiple stressors on running water ecosystems? Freshwater Biology 55, 80-119.

Stein, E. D., Martinez, M. C., Stiles, S., Miller, P. E., and Zakharov, E. V. (2014). Is DNA Barcoding Actually Cheaper and Faster than Traditional Morphological Methods: Results from a Survey of Freshwater Bioassessment Efforts in the United States? Plos One 9.

Stubauer, I., Hering, D., Korte, T., Hoffmann, A., Brabec, K., Sharma, S., Shrestha, M., Kahlown, M. A., Tahir, M. A., Kumar, A., Sharma, M. P., Bari, M. F., Badruzzaman, A. B. M., Chhopel, G. K., and Moog, O. (2010). The development 
of an assessment system to evaluate the ecological status of rivers in the Hindu Kush-Himalayan region: introduction to the special feature. Hydrobiologia 651, 115.

Suter, G. W., and Cormier, S. M. (2014). Why care about aquatic insects: uses, benefits and services Integrated Environmental Assessment and Management 11, 188-194.

Thomson, J. R., Thompson, R. M., Metzeling, L., Reich, P., Bond, N. R., Cunningham, S. C., and Mac Nally, R. (2012). The influence of vegetation, flows and climate variation on stream biota: lessons from the big dry in southern Australia. . Global Change Biology 18, 1582-1596.

Tolonen, K. T., Hamalainen, H., Lensu, A., Merilainen, J. J., Palomaki, A., and Karjalainen, J. (2014). The relevance of ecological status to ecosystem functions and services in a large boreal lake. Journal of Applied Ecology 51, 560-571.

Tullos, D. D., Penrose, D. L., Jennings, G. D., and Cope, W. G. (2009). Analysis of functional traits in reconfigured channels: implications for the bioassessment and disturbance of river restoration. Journal of the North American Benthological Society 28, 80-92.

USEPA (2009). National Aquatic Resource Surveys: A Progress Report. USEPA Office of Wetlands, Oceans, and Watersheds (4503T), EPA 841-F-08-001.

USEPA (2013). United States Environmental Protection Agency. Biological assessment program review: assessing level of technical rigor to support water quality management. EPA 820-R-13-001 (Office of Science and Technology, Washington, DC)

WFD (2000). Water Framework Directive of the European Parliament and the Council, of 23 October 2000, Establishing a framework for Community action in the field of water policy. Official Journal of the European Communities L327, 1-72.

White, H. L., Nichols, S. J., Robinson, W. A., and Norris, R. H. (2012). More for less: a study of environmental flows during drought in two Australian rivers. Freshwater Biology 57, 858-873.

Woodward, G., Gray, C., and Baird, D. J. (2013). Biomonitoring for the 21 st Century: new perspectives in an age of globalisation and emerging environmental threats. Limnetica 32, 159-173.

Wright, J. F., Sutcliffe, D. W., and Furse, M. T. (2000). 'Assessing the Biological Quality of Fresh Waters: RIVPACS and Other Techniques.' (Freshwater Biological Association: Ambleside, Cumbria, U.K)

Yoder, C. O., and Barbour, M. T. (2009). Critical technical elements of state bioassessment programs: a process to evaluate program rigor and comparability. Environmental Monitoring and Assessment 150, 31-42. 
Table 1. Examples of the value/benefit of bioassessment for different stakeholders and how results could be communicated. Please note that the stated benefits and

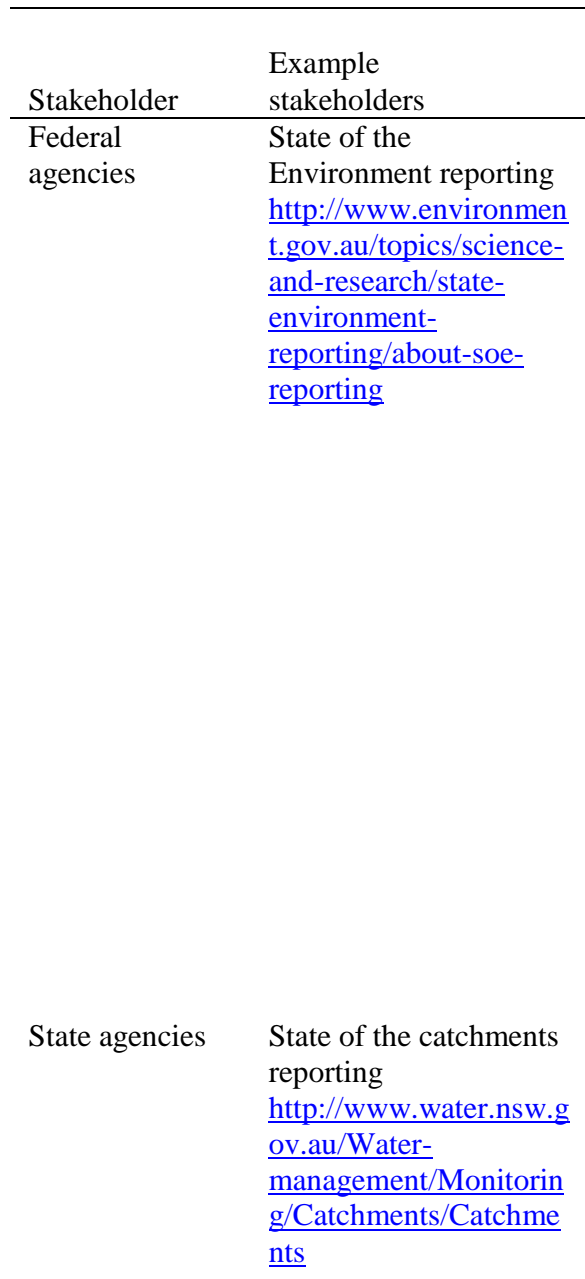

Water suppliers Compliance monitoring https://www.iconwater. com.au/Sustainabilityand-

Environment/Environm entalcompliance/Operational \%20compliance\%20rep orts.aspx

Irrigation $\quad$ http://npsi.gov.au/nation companies al-land-and-waterresources-audit/riversand-wetlands
Value/benefit

(examples of what is in it for them)

1. Provides information to decision makers (Federal and State Ministers) to inform environmental policy, investment and management

2. Provides public with current information on the state of Australia's environment

3. Assessment also used to meet reporting obligations for national legislation (EPBC Act) and international agreements

4. Measures progress towards national natural resource condition targets

5. Increased environmental awareness and engagement for sustainable natural resources

6. Provides the public with an assessment of the condition of natural resources in a region

7. Informs policy and investment decisions within and between regions

8. Assess ecological recovery following restoration of aquatic resources

9. Measures progress towards regional natural resource condition targets

10. The ability to report on and inform management actions

11. The ability to report on the positive effect on the environment of optimizing the use of fertiliser and minimising runoff to rivers.
Example of how results could be communicated, reported or understood. Assessment scores and trends for inland waters, taxa distributions, map layers linked to other national-scale information i.e. biodiversity, climate change, landuse.

An indication of the quality of evidence used to make the assessment

Evidence synthesized in a way that allows the reader to access further detail if required

Assessment scores for inland waters, report cards, and maps.

Taxa lists, food web diagrams, ecological information for community educational use

An indication of the quality of evidence used to make the assessment.

Report results to determine if restoration efforts are attaining their purpose.

Assessment scores over time Diagnostic interpretation

Reports to regulators and board of directors 


\begin{tabular}{|c|c|c|c|c|}
\hline $\begin{array}{l}\text { Mining } \\
\text { companies }\end{array}$ & $\begin{array}{l}\text { Assess the } \\
\text { environmental } \\
\text { performance } \\
\text { http://mrmindependent } \\
\text { monitor.com.au/ }\end{array}$ & 12. & $\begin{array}{l}\text { Provides their stakeholders } \\
\text { with information relating to } \\
\text { their environmental } \\
\text { performance. }\end{array}$ & $\begin{array}{l}\text { Reports to regulators and board of } \\
\text { directors }\end{array}$ \\
\hline \multirow[t]{3}{*}{$\begin{array}{l}\text { Community- } \\
\text { based groups }\end{array}$} & $\begin{array}{l}\text { ACT Waterwatch } \\
\text { Catchment Health } \\
\text { Indicator Program } \\
\text { (CHIP) } \\
\text { http://www.act.waterwa }\end{array}$ & 13. & $\begin{array}{l}\text { Determine recovery or } \\
\text { maintenance of ecological } \\
\text { condition in response to a } \\
\text { community led intervention. }\end{array}$ & $\begin{array}{l}\text { Report cards that integrate other } \\
\text { measures of catchment or reach } \\
\text { condition and summarize multiple } \\
\text { indices by using 'traffic light' } \\
\text { symbols and 'pie chat' graphics. }\end{array}$ \\
\hline & $\begin{array}{l}\frac{\text { tch.org.au/Files/CHIP20 }}{13 \text { 14\%20Report\%200 }} \\
\text { 4FEB2015_FINAL\%20 } \\
\text { \%281ow\%20res\%29.pdf }\end{array}$ & 14. & $\begin{array}{l}\text { Facilitate community } \\
\text { engagement in the monitoring } \\
\text { and care of local waterways }\end{array}$ & \\
\hline & $\begin{array}{l}\text { and South East } \\
\text { Queensland (SEQ) } \\
\text { Healthy Waterways } \\
\text { http://healthywaterways } \\
\text {.org/reportcard\#/sub- } \\
\text { regions/2014/overview }\end{array}$ & 15. & $\begin{array}{l}\text { Provide data and information } \\
\text { to support an early warning } \\
\text { system for aquatic ecosystem } \\
\text { health issues. }\end{array}$ & \\
\hline $\begin{array}{l}\text { Recreational } \\
\text { groups }\end{array}$ & Club websites & 16. & $\begin{array}{l}\text { Information to allow them to } \\
\text { choose the most appropriate } \\
\text { waterways for their } \\
\text { recreational pursuits }\end{array}$ & $\begin{array}{l}\text { Water quality score cards, } \\
\text { fish survey data, } \\
\text { primary pollutants }\end{array}$ \\
\hline Tourism & Tourist maps & 17. & $\begin{array}{l}\text { Information to provide to } \\
\text { tourists who have an interest } \\
\text { in the natural environment } \\
\text { and to eco-tourism operators }\end{array}$ & $\begin{array}{l}\text { Water quality score cards, } \\
\text { biodiversity score cards }\end{array}$ \\
\hline Real Estate & Property profiles & 18. & $\begin{array}{l}\text { Information to provide to } \\
\text { investors that could affect } \\
\text { property values }\end{array}$ & $\begin{array}{l}\text { Water quality score cards, } \\
\text { primary pollutants, } \\
\text { land use }\end{array}$ \\
\hline \multirow[t]{2}{*}{ Local Councils } & $\begin{array}{l}\text { Annual (or quarterly } \\
\text { reporting), score cards }\end{array}$ & 19. & $\begin{array}{l}\text { Information to provide to } \\
\text { residents and visitors for } \\
\text { tourism, investment or } \\
\text { recreational purposes }\end{array}$ & $\begin{array}{l}\text { Water quality score cards, } \\
\text { biodiversity score cards, } \\
\text { primary pollutants }\end{array}$ \\
\hline & & 20. & $\begin{array}{l}\text { Provides detail for state of } \\
\text { environment reporting at a } \\
\text { local scale }\end{array}$ & \\
\hline Education & $\begin{array}{l}\text { Reports, academic } \\
\text { publications }\end{array}$ & 21. & $\begin{array}{l}\text { Information for report- } \\
\text { writing, academic researcher } \\
\text { or education (e.g. high } \\
\text { school), including ongoing } \\
\text { monitoring projects and } \\
\text { research }\end{array}$ & $\begin{array}{l}\text { Methods, } \\
\text { water quality score cards, } \\
\text { biodiversity score cards, diagnostic } \\
\text { 'story telling' }\end{array}$ \\
\hline
\end{tabular}


Table 2. Examples of state-wide and regional bioassessment programs in Australian jurisdictions, both government and community-driven.

\begin{tabular}{|c|c|c|c|}
\hline \multicolumn{2}{|c|}{$\begin{array}{l}\text { Example of state-wide or regional } \\
\text { scale bioassessment programs }\end{array}$} & \multirow{2}{*}{$\begin{array}{l}\text { Objective of bioassessment } \\
\text { Protecting the water quality of } \\
\text { Victoria's inland waters }\end{array}$} & \multirow{2}{*}{$\begin{array}{l}\text { Reference } \\
\text { http://www.epa.vic.gov.au/your- } \\
\text { environment/water/protecting- } \\
\text { victorias-waters/monitoring- } \\
\text { victorias-waters }\end{array}$} \\
\hline 1. & Victoria & & \\
\hline 2. & New South Wales & Water quality management & $\begin{array}{l}\text { http://www.water.nsw.gov.au/Water- } \\
\text { management/Monitoring/Monitoring }\end{array}$ \\
\hline 3. & Tasmania & Water quality management & $\begin{array}{l}\text { http://dpipwe.tas.gov.au/water/wate } \\
\text { r-monitoring-and-assessment }\end{array}$ \\
\hline 4. & $\begin{array}{l}\text { Basslink monitoring } \\
\text { program in Gordon } \\
\text { River system, Tasmania } \\
\text { by Hydro Tasmania, } \\
\text { Hobart (from 2001- } \\
\text { 2012) }\end{array}$ & $\begin{array}{l}\text { To detect changes in key biological } \\
\text { variables through time associated with } \\
\text { large power generating projects }\end{array}$ & $\begin{array}{l}\text { www.hydro.com.au/environment/ba } \\
\text { sslink-studies }\end{array}$ \\
\hline 5. & $\begin{array}{l}\text { The Living Murray } \\
\text { program (TLM) }\end{array}$ & $\begin{array}{l}\text { River basin ecological condition of the } \\
\text { Murray Basin }\end{array}$ & $\frac{\text { http://www.mdba.gov.au/media- }}{\text { pubs/publications/tlm-program }}$ \\
\hline 6. & $\begin{array}{l}\text { Sustainable Rivers } \\
\text { Audit (SRA) }\end{array}$ & $\begin{array}{l}\text { Federally-funded programs at single } \\
\text { ecosystem unit to river basin scales. }\end{array}$ & $\begin{array}{l}\text { http://www.mdba.gov.au/what-we- } \\
\text { do/mon-eval-reporting/sustainable- } \\
\text { rivers-audit; Davies et al. }(2010)\end{array}$ \\
\hline 7. & $\begin{array}{l}\text { Commonwealth } \\
\text { Environment Water } \\
\text { Holder Long-Term } \\
\text { Intervention Monitoring } \\
\text { (CEWH LTIM) (at } \\
\text { catchment scales over } \\
\text { 5-7 years). }\end{array}$ & $\begin{array}{l}\text { To evaluate the success of investments } \\
\text { in environmental flows }\end{array}$ & $\begin{array}{l}\text { http://www.environment.gov.au/wat } \\
\text { er/cewo/monitoring }\end{array}$ \\
\hline 8. & $\begin{array}{l}\text { Commonwealth } \\
\text { Environment Water } \\
\text { Holder Long-Term } \\
\text { Intervention Monitoring } \\
\text { (CEWH LTIM) }\end{array}$ & Catchment scales over 5-7 years. & $\begin{array}{l}\text { http://www.environment.gov.au/wat } \\
\text { er/cewo/monitoring }\end{array}$ \\
\hline 9. & $\begin{array}{l}\text { Australian Capital } \\
\text { Territory (ACT) water } \\
\text { monitoring and } \\
\text { assessment program ( } 13 \\
\text { fixed sites within } 2,400 \\
\mathrm{~km}^{2} \text {, ongoing since } \\
1996)\end{array}$ & $\begin{array}{l}\text { To determine changes to water quality } \\
\text { over time and indicate if waters } \\
\text { flowing through the ACT are of } \\
\text { appropriate quality and management } \\
\text { strategies are achieving or maintaining } \\
\text { adequate water quality. }\end{array}$ & $\begin{array}{l}\text { http://www.environment.act.gov.au/ } \\
\text { water/act_water_reports }\end{array}$ \\
\hline 10. & $\begin{array}{l}\text { ACT Environmental } \\
\text { Flows monitoring } \\
\text { program (15 sites } \\
\text { sampled since } 2000 \text { but } \\
\text { other smaller scale } \\
\text { studies undertaken } \\
\text { since 1996). }\end{array}$ & $\begin{array}{l}\text { To assess the effects of } \\
\text { dam operation, water abstraction, and } \\
\text { environmental flows, and to provide } \\
\text { information for the adaptive } \\
\text { management of ACT's water supply } \\
\text { catchments in accordance to the } \\
\text { License to Take Water (WU67). }\end{array}$ & $\begin{array}{l}\text { http://www.actew.com.au/Water- } \\
\text { Supply-System/Environmental- } \\
\text { Flows.aspx see Aquatic Ecology } \\
\text { Reports available from } \\
\text { http://www.actew.com.au/About/Re } \\
\text { ports-and-Publications/Key- } \\
\text { Publications.aspx }\end{array}$ \\
\hline 11. & $\begin{array}{l}\text { ACT Waterwatch } \\
\text { Catchment Health } \\
\text { Indicator Program } \\
\text { (ACT Waterwatch } \\
\text { program running since } \\
1995 \text { within } \\
13,000 \mathrm{~km}^{2} \text { ) }\end{array}$ & $\begin{array}{l}\text { Provide community with understanding } \\
\text { of water quality and riparian health in } \\
\text { their catchment and provide baseline } \\
\text { assessment of catchment health to } \\
\text { assist natural resource managers and } \\
\text { policy. }\end{array}$ & $\begin{array}{l}\text { http://www.act.waterwatch.org.au/F } \\
\text { iles/CHIP2013_14\%20Report\%200 } \\
\text { 4FEB2015_FINAL\%20\%28low\%2 } \\
\text { Ores\%29.pdf }\end{array}$ \\
\hline 12. & $\begin{array}{l}\text { SEQ Healthy } \\
\text { Waterways (since } 2000 \\
\text { monitored } 15 \\
\text { catchments with a } \\
\text { combined area } \sim 23,000 \\
\mathrm{~km}^{2} \text { ) }\end{array}$ & $\begin{array}{l}\text { To understand and communicate the } \\
\text { condition of waterways to drive and } \\
\text { influence future targets, policy and } \\
\text { actions. Monitor and report on } \\
\text { waterway health, educate people on the } \\
\text { value of our waterways and support } \\
\text { reforms to policy and planning. }\end{array}$ & $\begin{array}{l}\text { http://healthywaterways.org/reportc } \\
\text { ard\#/sub-regions/2014/overview; } \\
\text { Bunn } \text { et al. }(2010)\end{array}$ \\
\hline
\end{tabular}


Table 3. Five attributes that broad-scale (national or multijurisdictional) bioassessment programs should have to be successful.

\begin{tabular}{|c|c|}
\hline $\begin{array}{l}\text { Attributes for } \\
\text { success }\end{array}$ & Description \\
\hline $\begin{array}{l}\text { 1. A mandate, } \\
\text { either } \\
\text { political or } \\
\text { public }\end{array}$ & $\begin{array}{l}\text { The program must serve a purpose or defined need and fit } \\
\text { within a management and policy framework e.g. to provide } \\
\text { State of Environment reports, assess adequacy of regulations, } \\
\text { and/or to determine effectiveness of policies and } \\
\text { management actions. }\end{array}$ \\
\hline $\begin{array}{l}\text { 2. Political } \\
\text { context and } \\
\text { governance }\end{array}$ & $\begin{array}{l}\text { A program that has a mandate needs dedicated program } \\
\text { funding, coordination and the associated governance } \\
\text { structure to support such a program. This is particularly } \\
\text { important for monitoring programs that by their nature } \\
\text { require a long-term commitment. }\end{array}$ \\
\hline $\begin{array}{l}\text { 3. Must be fit } \\
\text { for purpose }\end{array}$ & $\begin{array}{l}\text { The program must provide users with the information } \\
\text { required and fit within a larger environmental and resource } \\
\text { management framework. The output from the program must } \\
\text { be transparent and the interpretation evident. }\end{array}$ \\
\hline $\begin{array}{l}\text { 4. Clear } \\
\text { objectives }\end{array}$ & $\begin{array}{l}\text { This links to item } 1 \text { above (e.g. for early warning, status and } \\
\text { trends or adequacy of regulations) with } a \text { priori agreement on } \\
\text { targets, guidelines or standards for further action or reporting. } \\
\text { National-scale bioassessment programs need to be tied to } \\
\text { quantified national-scale ecological objectives and } \\
\text { management outcomes if they are to be relevant to policy and } \\
\text { investment. }\end{array}$ \\
\hline $\begin{array}{l}\text { 5. Be current } \\
\text { and relevant }\end{array}$ & $\begin{array}{l}\text { The balance between consistency in data over time and } \\
\text { incorporating or considering developments in science is } \\
\text { difficult but needs to be continually addressed. }\end{array}$ \\
\hline
\end{tabular}


Table 4. Comparison of four national scale aquatic bioassessment programs against five attributes that should be met in order to deliver a successful program.

\begin{tabular}{|c|c|c|c|c|c|}
\hline $\begin{array}{l}\text { Bioassessment } \\
\text { Program (and } \\
\text { assessment } \\
\text { method in } \\
\text { brackets) }\end{array}$ & Mandate & $\begin{array}{c}\text { Political } \\
\text { context and } \\
\text { governance }\end{array}$ & $\begin{array}{c}\text { Fit for } \\
\text { purpose }\end{array}$ & $\begin{array}{c}\text { Clear } \\
\text { objectives }\end{array}$ & $\begin{array}{l}\text { Current } \\
\text { and } \\
\text { relevant }\end{array}$ \\
\hline $\begin{array}{l}\text { Australia } \\
\text { (AUSRIVAS) }\end{array}$ & $\begin{array}{l}\text { Strong } \\
\text { initially, } \\
\text { currently } \\
\text { absent }\end{array}$ & $\begin{array}{l}\text { Regionalized } \\
\text { and lacks high } \\
\text { priority } \\
\text { national policy } \\
\text { drivers }\end{array}$ & $\begin{array}{l}\text { Yes, but } \\
\text { there are } \\
\text { concerns } \\
\text { that } \\
\text { methods } \\
\text { are not } \\
\text { universally } \\
\text { fit for } \\
\text { purpose }\end{array}$ & $\begin{array}{l}\text { Initially, } \\
\text { clear and } \\
\text { well } \\
\text { developed. } \\
\text { Currently, } \\
\text { no national } \\
\text { quantified } \\
\text { objectives. }\end{array}$ & $\begin{array}{l}\text { Resource } \\
\text { limitations }\end{array}$ \\
\hline $\begin{array}{l}\text { UK } \\
\text { (RIVPACS) }\end{array}$ & $\begin{array}{l}\text { Strong } \\
\text { national and } \\
\text { international } \\
\text { legislation - } \\
\text { European } \\
\text { Union } \\
\text { Water } \\
\text { Framework } \\
\text { Directive }\end{array}$ & $\begin{array}{l}\text { Clear national } \\
\text { and supra } \\
\text { national }\end{array}$ & Yes & $\begin{array}{l}\text { Clear and } \\
\text { well } \\
\text { developed }\end{array}$ & Yes \\
\hline $\begin{array}{l}\text { Canada } \\
\text { (CABIN) }\end{array}$ & $\begin{array}{l}\text { Never well } \\
\text { developed }\end{array}$ & $\begin{array}{l}\text { Weak Federal } \\
\text { responsibility, } \\
\text { under the } \\
\text { constitution }\end{array}$ & $\begin{array}{l}\text { Yes but } \\
\text { difficult to } \\
\text { maintain }\end{array}$ & $\begin{array}{l}\text { Clear and } \\
\text { well } \\
\text { developed }\end{array}$ & $\begin{array}{l}\text { Resource } \\
\text { limitations }\end{array}$ \\
\hline $\begin{array}{l}\text { USA National } \\
\text { Aquatic } \\
\text { Resource } \\
\text { Surveys (both } \\
\text { multi-metric } \\
\text { indices and } \\
\text { RIVPACS- } \\
\text { type) }\end{array}$ & $\begin{array}{l}\text { Strong } \\
\text { national } \\
\text { legislation - } \\
\text { US Clean } \\
\text { Water Act }\end{array}$ & $\begin{array}{l}\text { Clear } \\
\text { partnerships } \\
\text { between } \\
\text { national and } \\
\text { state/tribal } \\
\text { agencies }\end{array}$ & $\begin{array}{l}\text { Yes, since } \\
2006\end{array}$ & $\begin{array}{l}\text { Clear and } \\
\text { well } \\
\text { developed }\end{array}$ & Yes. \\
\hline
\end{tabular}




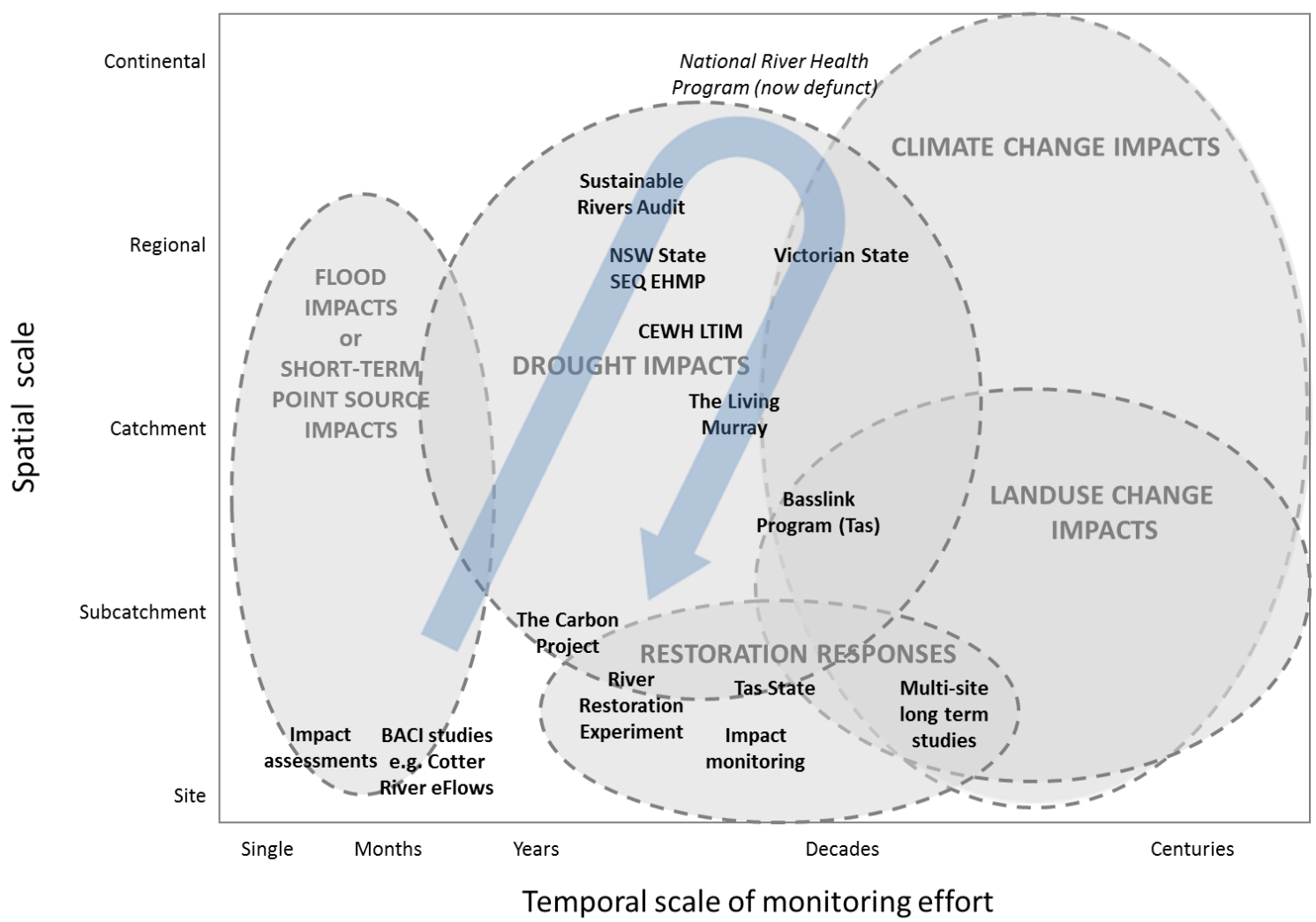

Fig. 1. Bioassessment programs and selected major management issues for Australia, temporal scale axis refers to a single sampling occasion. The curved arrow shows the trend for a description of the bioassessment programs. 


\begin{tabular}{|c|c|c|c|}
\hline $\begin{array}{l}\text { Initial } \\
\text { tasks }\end{array}$ & $\begin{array}{l}\text { Establish leadership and a } \\
\text { bioassessment blueprint. } \\
\text { Identify key national } \\
\text { ecological objectives } \\
\text { related legislative/policy } \\
\text { instruments around which } \\
\text { to design bioassessment }\end{array}$ & $\begin{array}{l}\text { Secure web host for shared } \\
\text { resources }\end{array}$ & $\begin{array}{l}\text { Promote national } \\
\text { ecological objectives for } \\
\text { aquatic ecosystems and the } \\
\text { role of bioassessment }\end{array}$ \\
\hline $\begin{array}{l}\text { Later } \\
\text { tasks }\end{array}$ & $\begin{array}{c}\text { Design and develop } \\
\text { proposals to address } \\
\text { objectives, respond to calls }\end{array}$ & $\begin{array}{c}\text { Trial web-enabled } \\
\text { interactions e.g. prepare } \\
\text { guidelines and joint } \\
\text { proposals }\end{array}$ & $\begin{array}{l}\text { Share viewpoints or } \\
\text { resources from existing } \\
\text { bioassessment programs }\end{array}$ \\
\hline Only & & & \\
\hline $\begin{array}{l}\text { ossible } \\
\text { with }\end{array}$ & $\begin{array}{c}\text { Research and enhance } \\
\text { bioassessment approaches }\end{array}$ & $\begin{array}{l}\text { Build and implement a } \\
\text { Bioassessment exchange }\end{array}$ & $\begin{array}{l}\text { Coordinate local, regional } \\
\text { and national bioassessment }\end{array}$ \\
\hline
\end{tabular}

Fig. 2. Pathway for modernizing freshwater bioassessment in Australia. While the initial and later tasks would require some level of resourcing, we emphasise that funding is essential to achieve the third layer. 